\title{
Organizing Sports around the Workplace - some Experiences from Scandinavian Company Sport
}

\section{Henning Eichberg}

\author{
University of Southern Denmark, Centre for Sport, Health and Civil Society, \\ Gerlev
}

ABSTRACT

KEYWORDS

\begin{abstract}
There are different ways of placing sports in social life, and the workplace is one of them. The Scandinavian countries are internationally renowned for their particular development of company sport. This is linked to the dynamics of the Nordic welfare society and political concern about 'public health'. On the basis of recent Danish research, current practices of company sport are examined. There is social change inside company sport, and new strata demand more and wider offers of sport in the workplace. Side by side with sport in specialized clubs, sport in local-cultural 'popular' associations and sport in commercial institutes, sport in the workplace, thus, has a future. This challenges the traditional division of everyday life under capitalist conditions: collective work here, private leisure there. People's health as a human right under the conditions of developing capitalism changes the agenda, also for sports.

corporation sports, sport organizations, Denmark, sport for all, people's health, enterprise culture
\end{abstract}

There are different ways of placing sports in social life, and the workplace is one of them. The Scandinavian countries are internationally renowned for their particular development of company sport.

Also in the Nordic countries, however, sport in the workplace is not the most common way of doing it, as compared with sports in clubs and sports in commercial institutes. But the connection between sport and the community of work - with the corporation or company - has its own logic. And according to recent research from Denmark, company sport seems to have a future.

\section{Three settings of sports in Denmark}

In Denmark, one finds three different traditional settings of sport, which have found their expression in three different types of organizations - one referring to the activities, another to the local culture and a third to the workplace. The plurality of organizations is, thus, not quite accidental, but related to different social patterns in sports. It is true that organizations do not directly reflect the different social relations in practical sports, indeed they even tend to blur them as they are increasingly 
competing on the same market of media and public support. But nevertheless, each organization shows a certain mix, resulting from some deeper body-cultural difference.

On the one hand, sport can be practised as a way of obtaining technical excellence in certain specialized activities or disciplines, and this is realized by competition. The competitive side of sports is organized in clubs of special activities, which form national federations of special disciplines. The umbrella organization of this type of sport is the Sports Confederation of Denmark (DIF), which includes the National Olympic Committee. Sport of disciplines is the international mainstream.

On the other hand, sport is an element of local culture, which is displayed at festivities and festivals. Here, the different activities are more connected with each other, which in Denmark happened under the traditional dominance of gymnastics. The local-cultural side of sports is organized in multi-activity clubs. On the regional and national levels, the local-cultural dimension of sports was traditionally administered by the Danish Gymnastics and Sports Associations (DGI), which have their historical roots in the democratic farmers' gymnastic movement of the nineteenth century and the people's academies. Recent social change, however, has brought this setting into some crisis and confusion. The multi-activity clubs are stagnating and have difficulties recruiting leaders under the conditions of increasing bureaucratic demands. Local culture disappears, and people replace it with their more specialized cultural engagements. The umbrella organization DGI is currently seeking new orientations towards welfare sports and public health.

As a third pattern, sport is a joint activity linked to people's workplace. This is traditionally organized by clubs and enterprises, which are members of the Danish Federation of Company Sports (DFIF). The federation has 340,000 members, which is fewer than DIF and DGI with their 1,5 million each, but nevertheless remarkable.

\section{Different ways towards Scandinavian welfare sports}

Comparative figures from Finland and Germany show the relative significance of sport in connection with the workplace in the North. In regional surveys it showed that people were much more active in sport in the workplace in Finland (14\%) than in the Germanies (around 5\%). In the Finnish region of Pirkanmaa, sport in the workplace is at the same scale as sport in clubs (15\%) and in institutes of commercial providers (17\%). All these are, however, somewhat beneath the extent of sports in municipal "community institutions" $(26 \%)$, e.g. adult education programmes, which have a strong position in the landscape of organized Finnish sports (Ståhl 2002, p. 241). ${ }^{1}$

The marked position of sport in the workplace seems to be connected with the particular model of the Scandinavian welfare society. The welfare society is not only a form of public political organization, which is organized in the welfare state, but it also influences civil society (with its logic of voluntariness) and enterprises (following the commercial market logic).

However, the development of company sports in the Nordic countries was not uniform. There were different paths through history, which led to the relatively strong current position of company sport and sport in the workplace in Scandinavia (Eichberg 1993/94).

In Denmark, company sport is strongly oriented towards social encounter and togetherness (samvær). Company sport has developed side by side with 'popular' (folkelig) sport (DGI), which came historically from the farmers' gymnastics, and it has been influenced by the folkelig practice of 'association' (forening) and 'meeting' (stævne).

\footnotetext{
${ }^{1}$ For figures from Norway see Dølvik 1988: 69-75.
} 
In Norway, by contrast, the early history of company sport was marked by a rigorous class struggle, which divided Norwegian sport more generally into 'red' and 'white' sport. On the one hand, socialist workers organized company sport, bedriftsidrett, as an important form of their socialist selforganization. On the other side, corporation sport, korporationsidrett, was built up in order to promote social peace and discipline under the central organization of bourgeois sport, administered by entrepreneurs and military officers. This picture changed in the 1940s, in connection with social change. Also the troubles of World War II contributed to the unification of Norwegian sports in a central organization (NIF). Company sports were unified, too. The traditions of workers' sport remained alive in Norwegian company sports; however, they lost their 'alternative' character and changed gradually towards an overall agenda of public health (folkesundhed).

In Sweden, far more than in the other Nordic countries, sport is characterized by unitary organization (RF). Swedish sport neither knew a powerful workers' sport movement like in Norway nor a folkelig farmers' gymnastic movement like in Denmark. Company sport was therefore always a part of the 'one sport', though following its own organizational patterns. Inside the unitary concept of sport, company sport took an early and strong turn towards public health, called friskvård and hälso. The importance of Swedish friskvård and hälso seems to witness of a certain influence from frisksport, which in the period between the World Wars was a special Swedish practice of connecting sport with a more general reform of life - bodybuilding, outdoor life, nutrition, naturism and health. While frisksport was a more sub-cultural phenomenon - like the contemporary socialist concept of people's health, folkesundhed - the new public health tends to become mainstream, merging with the more private wave of fitness, motion and wellness.

The outcome of these different paths was, however, a common pattern: Scandinavian welfare society giving company sport a relatively remarkable position.

\section{Current demands and challenges}

Recent investigation into company sport in Denmark has shown that people participate in company sport to a very limited degree. But far more of them have positive wishes towards sport in the workplace, and they would like to practise this type of sport much more than it is currently offered.

Questionnaire investigation in workplaces in Kolding and Roskilde showed that $83 \%$ of the respondents played sport actively. $12 \%$ were active in company sport, but no less than $43 \%$ wished to play company sport or sport in the workplace. Company sport mostly takes the form of ball games (7\%). To a minor extent, one practises bowling (2\%), bodybuilding and spinning (2\%), and outdoor motion (1-2\%). Among the desired activities, ball games are also at the top (21\%). However, they are followed by bodybuilding and spinning (20\%), gymnastics, aerobics and relaxation (14\%), outdoor motion (11\%), and to lesser degree swimming and other water sports $(6 \%)$ and dance $(4 \%)$. While the typical active participant in company sports is a man of brief formal education, wishes come to a much higher degree from women, younger people and people with longer formal education (Ibsen 2005 a).

These wishes from below encounter political goodwill from above. In a time of growing concern about obesity, lifestyle illness and other health risks of modern life, public health is acquiring increasing 'status' and is more and more often connected with wishes to develop company sport (Roessler, Berggren 2005). In 1989, the Danish government formulated a "Programme of prevention", which underlined the need for physical activity and motion in the workplace. In the 1990s, the Danish directorate of health followed this up by issuing a paper about motion as a contribution for "a more healthy workplace" (Sundhedsstyrelsen 1997). And in 2002, the Danish ministry of interior and health affairs appealed to "the associational Denmark together with public child-care institutions, schools and 
workplaces to take co-responsibility for health".

The governmental initiatives corresponded to strategies of the World Health Organization, formulated as early as 1978 in the Alma Ata Declaration "Health for all by 2000". The more challenging demands of this declaration - health as a human right - were, however, after all forgotten by many governments. Since 2000 , this neglect has been called to worldwide attention by the oppositional grassroots of the People's Health Movement. The aspect of sport in the workplace has, however, continually played a role for WHO Europe.

Also enterprises are interested in company sport and support it. The background of this support is - besides the interest in health and maintenance of physical productivity - a certain interest in the development of social coherence and social life inside the company, firmakultur. An inquiry in 1997/98 about 2500 workplaces showed that every fifth company with more than 100 employees had a personnel policy which included physical activity in the workplace (Skovgaard, Berggren 2000).

The recent Danish investigation from Kolding and Roskilde from 2005 revealed some new details. $40 \%$ of the respondents stated that their company supported the participation in sport and motion, and $33 \%$ had special facilities for this purpose. Some further details have to be regarded more cautiously, as they may reflect some more unintentional local circumstances. Most facilities in the two towns were placed at peoples' disposal by public institutions (education, hospitals, library, police $59 \%$ ) and private services (IT, media, trade unions $-13 \%$ ). But only a minority of companies was thought to have an explicit 'policy of motion' (mostly in private services, 14\%). The support of sport and motion was experienced as being strongest in private services (64\%), medical industry (55\%), banks (49\%), and crafts and industry (47\%), less so than in public institutions (30\%) and commerce (26\%) (Ibsen 2005 a, p. 40).

The inconsistencies inside this profile are worth deeper and more extensive investigation in the future. Anyway, a certain interest from companies is visible, making them an interesting partner of sports in civil society. But there is also social change inside company sport, and new strata demand more and wider offers of sport in the workplace.

\section{Company sport and sport at the work place - different patterns?}

The investigations also showed that one has to pay attention to some differences between company sport and sport in the workplace. These two forms of sport are not quite identical.

The difference is, seen from the surface of space and place, a question of physical distance and transportation. It makes a difference whether people after work initially go home and then afterwards meet in sports groups which are related to their work, or whether they play sports in the workplace itself. The distances and needs of transportation change with the dynamics of housing and mobility, i.e. with the cultural ecology of modern industrial-capitalist environment.

The difference has also a social unbalance: The profile of traditional company sport is or was more male, working class, and tends to be soccer, while the demands of sport in the workplace are more female, higher-educated and concern more varied activities.

This corresponds to differences in subjective motivation. People join traditional company sport typically for the sake of comradeship and fellowship. The new wave of motion in the workplace is, in contrast, driven by motivations of health and wellness. It remains, however, an open question, to what degree the new motivation of individual health is a matter of discourse, which expresses another, deeper agenda. The new striving towards 'individual health', 'fitness' and 'wellness' may express - in the smart words of the market and of mainstream policies - a reaction against the alienation of modern 
working life with its systematic production of loneliness and stress.

Last but not least, the two patterns may be subjected to different historical tendencies: While traditional company sports in Denmark during the last years seem to stagnate or decrease slowly, the interest in sport at the workplace is growing (Ibsen 2005 a, p. 8).

Another investigation on the island of Funen has recently confirmed the special profile and the possible success of sport at the workplace (Ibsen et al. 2005 b). It showed, however, also some features that may give reason for some critical reflection. Women had more pleasure in motion in the workplace, which consisted of pause exercises, while many men would have preferred more sporting and competitive forms. And: People had a large interest in sport in the workplace, indeed, but the share of those who were not interested, was clearly higher at the end of the project. And the number of those who were 'very interested' was lower at the end. Thus, the success of sport in the workplace depends in high degree on what the new body cultural 'offers' concretely look like. The question and challenge is whether and how a new movement culture can be developed - rather than extending wellestablished forms of gymnastics and sports to the world of work. Sport in the workplace opens up towards a new experimentation.

\section{People's health under the conditions of developing capitalism}

The recent research from Denmark shows furthermore, that there are some limits of the traditional engagement from the side of the companies, which deserve critical reflection. Sport during work-time has for instance still a minor place in the picture, and companies are not especially interested in developing this, as compared with company sport in leisure time. Another problem is the connection between positive projects in the field of sport in the workplace - and their continuation or discontinuation.

This was shown by a case in West Zealand, where a curtain manufacture with 30 employees took great pleasure in a project of company sport. 18 employees, including the owner of the enterprise, met once a week in a nearby sports hall, a few steps away from their workplace, for manifold forms of movement, swimming, gymnastics, play and game. The regional press followed the process with great attention. The project was accompanied by research, which cast light on the physical and psychical effects, as compared with a control group of 'inactive' people on the same workplace. There were positive effects of physical character registered, but the participants evaluated the psychological and social effects as most important. To meet one's colleagues across the different departments of work practical work, administration, leadership... - was regarded as an important experience (Roessler, Berggren 2005, Roessler, Bredahl 2006, Bredahl, Bredahl, Roesssler 2007).

However, the project also showed some characteristic limits of 'project culture' and its implementation. After the project phase, all participants desired a continuation. But it remained open, who would take the initiative afterwards, and how the initiative should be continued after the innovative start phase as permanent practice. After some months, in spite of all good wishes, the game was finished. Similar limitations were shown at a project in a workplace in Odense (Andreasen, Møller-Jørgensen 2004/5).

If sport in the workplace as healthy motion should be self-sustainable, some further investment is required. Especially investment of body-cultural and socio-psychological character is needed. Goodwill is not enough.

The architectural dimension is worth attention, too. For the future of sport in the workplace, the integration of facilities for work and for motion remains a desideratum. Combining the physical 
space of work with spaces of movement, play and game is a challenge for innovative architecture. And it costs money, which the corporations have to spend.

The current tendencies of company sport and sport in the workplace can also be read as a critical comment on some debates about the organizational politics of sport. Tendencies to unite sport into one central organization have been politically successful in some Nordic countries, but they can be confronted with the value of difference and organizational competition. In cases of experimentation like those around the workplace in late industrial capitalism and welfare society, a multiplicity of organizational approaches may be more favourable for innovation. Sport as local culture and festivity, sport as competitive specialization, sport in the workplace... - self-organization and variety in the field of civil society has remarkable advantages and contributes to bodily democracy.

After all, it gives some meaning that other countries look to the North for inspiration from Scandinavian company sport. Side by side with sport in activity-specialized clubs, sport in localcultural 'popular' associations, sport in municipal institutions and sport in commercial institutes, indeed, sport in the workplace does have a future. However, sport in the workplace shows that the capitalism in power has not yet fulfilled its cultural task.

Health is a human right, and this is especially true under the conditions of developing postindustrial capitalism. Health as a human right makes the grassroots of People's Health Movement mobilize worldwide. This social understanding of health together with people's demand for sport in the workplace challenges the traditional division of everyday life under capitalist conditions: collective work here, private leisure there - and democracy somewhere else. People's health as a human right under the conditions of developing capitalism changes the agenda, also for sports.

\section{REFERENCES}

Andreasen, M., Møller-Jørgensen, N. (2004/5). En setting-tilgang til sundhedsfremme på arbejdspladsen - TDCErhvervscenter i Odense. In Kurt Lüders \& Niels Vogensen (Eds.) Idratspaedagogisk Årbog. Gerlev: Bavnebanke, pp. 140-167.

Bredahl, T. G., Veje Bredahl, B., Roessler, K. K. (2007). Gardinfabrikken i bevagelse - en sundhedspsykologisk undersøgelse af krop, psyke og bevagelse. In Thomas Gjelstrup Bredahl \& Svendler Nielsen Ch. (Ed.) Sundhed $i$ bevagelse - udfordringer til et begreb. Copenhagen: Frydenlund \& Dansk Idrætspsykologisk Forum, pp. 99-114.

Dølvik, J. E.,, Danielsen, Ø., Hernes G. (1988). Kluss i vekslinga. Fritid, idrett og organisering. Oslo: FAFO.

Eichberg, H. (1993/94). Korporative Sozialhygiene? Zur Geschichte des Betriebssports in Skandinavien. In Beiträge zur Geschichte des Sports in Nordeuropa. (= Stadion. Special issue 19/20). Sankt Augustin: Academia 1993, pp. 37-67.

Ibsen, B. (2005 a). Den rummelige firmaidrat. Resultaterne af en unders $\phi g$ else af idrats- og motionsinteressen hos medarbejdere i virksomheder i Kolding og Roskilde. Nyborg: Dansk Firmaidrætsforbund, p. 51.

Ibsen, B. (2005 b). Motion på fynske arbejdspladser. Evaluering af projekt "Motion på fynske arbejdspladser”. Nyborg: Dansk Firmaidrætsforbund, p. 4.

Møller, S. (2004). Education in Danish company sport. In H. Eichberg (Ed.) Education through Sport: Towards an International Academy of Sport for All. Gerlev: International Movement Studies. In http://www.iasfa.org/literature.htm.

Roessler, K. K., Berggren, F. (2005). Sundhedsfremme på arbejdspladsen - med fokus på motion. Internet version at Idrottsforum - http://www.idrottsforum.org/articles/roessler_berggren/roessler_berggren050914.html

Roessler, K. K., Thomas Gjelstrup Bredahl (2006). Physical activity as part of health promotion in a work place - experiences from a health-psychological approach. International Journal of Eastern Sports and Physical Education, Suwon/Korea, vol. 4. 
Skovgaard, T., Berggren, F. (2000). Motion på arbejdet. Fokus idrat, 5-6, pp. 197-203.

Ståhl, T., Rütten, A. et al. (2002). The importance of policy orientation and environment on physical activity participation - a comparative analysis between Eastern Germany, Western Germany and Finland. Health Promotion International, 17: 3, pp. 235-246.

Sundhedsstyrelsen (1997). På vej mod et sundere arbejdsplads - Fokus på motion. Copenhagen. 